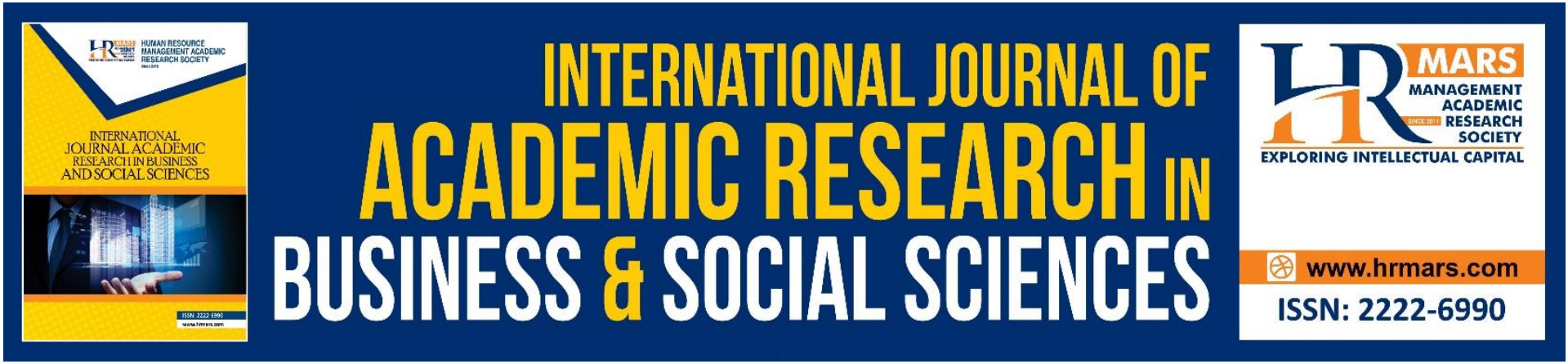

\title{
Role of Private Investment in Economic Growth in Pakistan: A Time Series Analysis (1980-2017)
}

Usama Anwar, Abdul Rehman Nawaz, Mirza Ali Raza, Amna Nasar, Ibrar Ahmad

To Link this Article: http://dx.doi.org/10.6007/IJARBSS/v11-i4/9185

DOI:10.6007/IJARBSS/v11-i4/9185

Received: 01 February 2021, Revised: 13 March 2021, Accepted: 15 March 2021

Published Online: 28 April 2021

In-Text Citation: (Anwar et al., 2021)

To Cite this Article: Anwar, U., Nawaz, A. R., Raza, M. A., Nasar, A., \& Ahmad, I. (2021). Role of Private Investment in Economic Growth in Pakistan: A Time Series Analysis (1980-2017). International Journal of Academic Research in Business and Social Sciences, 11(4), 378-391.

Copyright: @ 2021 The Author(s)

Published by Human Resource Management Academic Research Society (www.hrmars.com)

This article is published under the Creative Commons Attribution (CC BY 4.0) license. Anyone may reproduce, distribute, translate and create derivative works of this article (for both commercial and non-commercial purposes), subject to full attribution to the original publication and authors. The full terms of this license may be seen at: http://creativecommons.org/licences/by/4.0/legalcode

Vol. 11, No. 4, 2021, Pg. 378 - 391

Full Terms \& Conditions of access and use can be found at http://hrmars.com/index.php/pages/detail/publication-ethics 


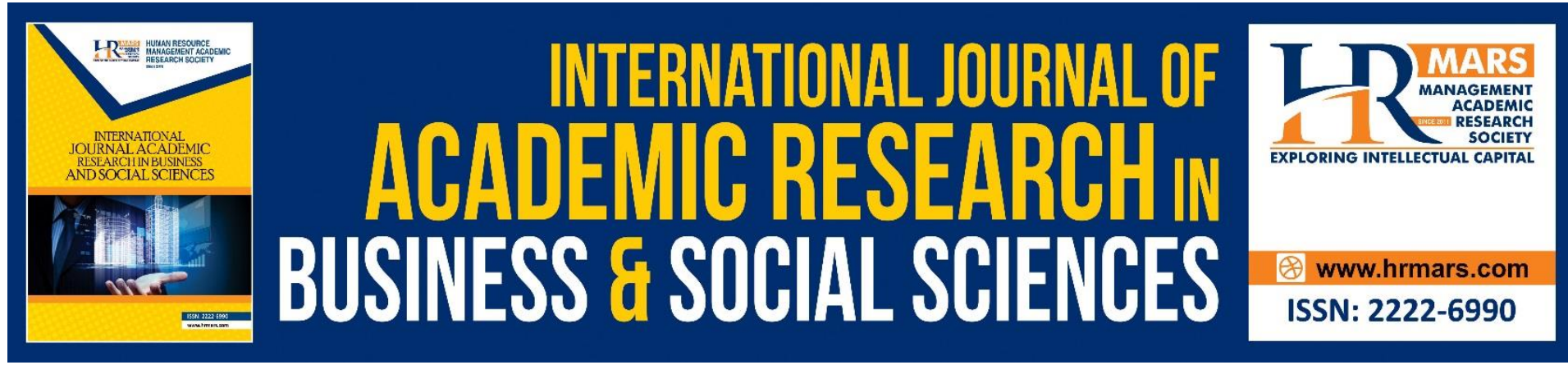

\title{
Role of Private Investment in Economic Growth in Pakistan: A Time Series Analysis (1980-2017)
}

\author{
Usama Anwar \\ Student of BS-Economics at School of Economics. Faculty of Business, Economics and \\ Administrative Sciences. University of the Punjab, Lahore, Pakistan. [Postal: 54590] \\ Email: usama.anwar309@gmail.com
}

Abdul Rehman Nawaz

Student of BS-Economics at School of Economics. Faculty of Business, Economics and Administrative Sciences. University of the Punjab, Lahore, Pakistan.

\section{Mirza Ali Raza}

Student of MPhil-Economics at School of Economics. Faculty of Business, Economics and Administrative Sciences. University of the Punjab, Lahore, Pakistan.

\section{Amna Nasar}

Student of BS-Economics at School of Economics. Faculty of Business, Economics and Administrative Sciences. University of the Punjab, Lahore, Pakistan.

\section{Ibrar Ahmad}

Student of MPhil-Management Sciences (Marketing). Lahore Leads University, Lahore, Pakistan.

\begin{abstract}
The paper examines the impact of private investment on Pakistan's economic growth through a time series analysis for the period 1980-2017. Economic growth is represented with real per-capita GDP, private sector credit as an envoy of private investment (DCPS), and other variables are foreign direct investment, the discount rate, and the inflation rate. The stationarity properties of the data are investigated through Augmented Dicky Fuller test (ADF), and ARDL co-integration technique is used to estimate the equation. The findings show a significant and negative association between LDPS and real GDP: that $1 \%$ increase (or decrease) in domestic credit to private sector, on average, causes a $0.7 \%$ decrease (or increase) in real per-capita GDP in the long-run. It is also found that discount rate and GDP deflator have a negative impact on economic growth. The study concluded that private investment has negative impact on economic growth in Pakistan. It recommends to build a favourable economic environment, and incentivize FDI in Pakistan due to its positive and significant impact on GDP.
\end{abstract}


Keywords: ARDL, Economic Growth, FDI, Pakistan, Private Investment

\section{Introduction}

Investments are significant for the progress of a country and play a constructive part in economic growth. Many developing countries depend on investment to address economic problems such as financial imbalance, the balance of payment, debt, poverty, and unemployment. Investment can be defined as the expenditures on capital goods to increase the productive capacity, with the aim to produce more goods and services and get better payoff in future (Kartikasari, 2017). Kirya and Yudiaatmaja (2015); Mohsen (2015) and gave empirical evidence to establish that investment has an influential impact on economic growth. Some evidence suggest that both public and private investment contribute to economic growth (Sari, Syechalad, \& Majid, 2016). There are three broad categories of investment: public investment, private investment, and foreign direct investment.

Public investment is made by the state or government owned institutions \& companies, that is usually targeted on public infrastructure like rail networks, bridges, ports, water \& sanitation network, energy plants- which can have a productive effect on general life. Sometimes, the governments use public investment policies to encounter economic recessions by increasing public expenditures and reducing taxes. UN describes the public investment as a "tool" to countercyclical fiscal policy (UN, 2019). Many scholars (e.g., Bivens (2012); Fournier (2016); Murty and Soumya (2007)) consider public investment crucial to economic growth.

Private investment is the component of an open-market economy that consists of business and organizations handled by private administration. The private section of the economy makes its own decisions to earn private profit by utilizing financial and physical capital. In other words, private sector consists of business organizations held by persons for their personal economic profit, thus contributing to the overall economic well-being of a country. But there are some barriers in the way of private investment like political instability (Ali, Hashmi, \& Hassan, 2013), domestic savings (Hundie, 2014; Mohan, 2008) and fluctuations in tax rates (Djankov et al. 2010). Ekpo (2016) observes that inflation, market size, infrastructure, public investment, political \& economic stability, interest rate, and business environment are also essential factors that influence private investment in Nigeria. The given facets are also observed in Pakistan's economy, and it is required to address these factors to get the desired outcome of private investment in Pakistan.

FDI is the investment of other countries in a foreign country. FDI may bring knowledge, skills, generate services, and bring innovation that can help implement the latest manufacturing method and thus enhance the productivity of a country. FDI introduces the organizational mechanisms, managerial skills and discovers concealed markets in the economy. It helps reduce barriers in the implementation of new equipment and improves worker and investment quality within a country. The positive role of FDI in economic growth is evident from the economic progress of many countries (Fadhil \& Almsafir, 2015; Popescu, 2014); Tuan, Ng, and Zhao (2009)).

The present study focuses on the role private investment in economic development in Pakistan using a time series analysis (1980-2017). The primary purpose is to empirically identify the impact of private investment in Pakistan. This study is divided into five sections; in section 1, the literature review offers theoretical and empirical evidence extracted from previous studies in this area; section 2 discusses the research design and methodology of the 
study; section 3 includes the results of the ADF model, Bound test and ARDL; and in section

4 , conclusion, policy recommendations and suggestions for future work are discussed.

\section{Literature Review}

Badawi (2005) evaluates the impact of credit policy, public investment, interest rate policies, and devaluation of currency on private investment, using vector autoregressive (VAR) and error-correction technique. The study is basically concerned with the role of macroeconomic policies in determining private investment in Sudan for the period 1969-1998. The results suggest that for public investment: crowding-out effect outweighs the crowding-in effect. The author also finds significant negative coefficients for interest rate, devaluation of currency, contractionary monetary policy, and restricting domestic credit to private sector.

Khan and Khan (2007) observe that, for Pakistan, non-traditional factors are more effective in determining the private investment in the country for the period of 1972-2005. They use ARDL co-integration approach, and show that the accelator principle and crowding-out effect are partially valid, whlist McKinnon-Shaw hypothesis is not varified in Pakistan's case. Intuitively, the cost of funds (e.g., real interest rate) and government investment have imperceptible effect on private investment, and only external debt is found to have a shortand long-run negative impact. The study concludes that non-traditional factors such as quality of institutions, entrepreneurial skills, and legal \& regulatory framework are relatively more significant determinants of private investment in Pakistan.

Osman (2014) investigates the impact of investment and growth performance in Saudi Arabia by employing time-series data (1974-2012). The study uses ARDL approach, in which GDP is dependent variable, and commercial bank deposits (DS), inflation rate (CPI), government expenditure (G), private sector credit (BF), and open economy (OPE) are taken as independent variables. The results demonstrate that private sector credit and gross domestic product are positively related in the long-run. This suggests that increasing credit liquidity to private sector would have a positive spillover effects on the economy.

Kalu and mgbemena (2015b) use Error Correction Model to estimate the equation for the determinants of economic growth in Nigeria from 1970 to 2012. The findings show that equilibrium exists between real GDP and government expenditure (GEXP), private investment (PINV), private consumption (PCON), and interest rate (INT) in the long- and as well as shortrun. The ECM results show that about $36 \%$ of instability involving short- and long-run credit availability to the private sector is covered within a year. Nwakoby and Bernard (2016) also conducted the similar analysis in Nigeria for a different period (1986-2014). The cointegration findings indicate the long-run relationship between private investment and economic growth.

Attefah and Enning (2016) look into the determinants of private investment from 1980-2010 in the case of Ghana. The coefficients determined by the multiple regression model show that credit availability, government investment, openness of the economy, external debt, democracy, and corporate tax significantly affect private investment. The study recommends that crowding-out effect can be diminished by having a tighter fiscal policy.

Abdaljawwada and Sarmidi (2018) study the impact of private investment on economic growth in Palestine from 1990 to 2015. The OLS estimation shows that domestic private investment (DPSI), FDI, and CPI positively effect GDP, while the effect of exchange rate and population growth is adverse and significant. The findings suggest that private investment is a ignificant determinants of economic growth in Palestine. 
All the above studies indicate that the private investemnt has an optimistic effect on growth performance in all the observed countries. On the contrary, some studies establish opposite association between these two macroeconomic variables. Mohamed and Sidiropoulos (2008) use private sector credit to study the impact of private investment on economic growth in Sudan by ARDL approach. It is observed that the credit to private sector has a negative impact but it is not significant. Samargandi, Fidrmuc, and Ghosh (2014) investigate a similar relation in the case of Saudi Arabia using the same ARDL approach. They conclude that private sector credit has a significantly negative impact on financial development in Saudi Arabia. These two studies also have also partly attributed the failure of the private sector due to the economic climate in those countries. Tahir, Shehzadi, Ali, and Ullah (2015) study the impact of credit availability to private sector and Pakistan's economic growth using regression analysis for the period 1973-2013. The regression results show that banking credit to private sector has an adverse and significant effect on economic growth in Pakistan .

The above discussion elaborates that the effects of private sector credit on economic growth have been mixed. While some studies show a positive impact, others failed to. These mixed results imply that there is yet no agreement in the size and way of connection between private sector investment and growth performance, especially in developing countries.

\section{Methodology}

This section describes how the analysis will be conducted. It includes the research design, description of variables, data sources, data analysis method, and model specification. The present analysis employs the Autoregressive distributed lag model to analyze the association between the variables.

\section{Source of Data}

The data used in the analysis is secondary time-series data of five variables retrieved for WDI (World Growth Indicator) and IFS (international foundation of science). The time period covered in this study is 38 years (1980 to 2017). The variables used in this study include RGDP, DCPS, DR, FDI and GDP-D. 


\section{Description of Variables}

Table 1 defines different characterstics of the variables.

Table 1: Explanation of Variables

\begin{tabular}{|c|c|c|c|c|}
\hline Variables & Symbol & Measurement scale & Definition & Source \\
\hline $\begin{array}{l}\text { Log of Real GDP } \\
\text { p.c.y }\end{array}$ & LRGDP & $\%$ & $\begin{array}{l}\text { Gross domestic product } \\
\text { divided by semi-annual } \\
\text { population. } \\
\text { It is designed without } \\
\text { creating assumption for } \\
\text { reduction of invented } \\
\text { assets or for reduction and } \\
\text { deprivation of natural } \\
\text { assets. }\end{array}$ & WDI \\
\hline $\begin{array}{l}\text { Log of Domestic } \\
\text { credit to } \\
\text { private sector }\end{array}$ & LDCPS & $\%$ of GDP & $\begin{array}{l}\text { DCPS mentions economic } \\
\text { funds offered to the } \\
\text { private region through } \\
\text { monetary corporation, } \\
\text { alike through credits, pay } \\
\text { for bonds or options and } \\
\text { trade credit and other } \\
\text { assets, to set up a state for } \\
\text { refund. }\end{array}$ & WDI \\
\hline FDI inflows & FDI & $\%$ of GDP & $\begin{array}{l}\text { FDI is net inflows offoreign } \\
\text { invesment. FDI is divided by } \\
\text { GDP. It is the reinvestment } \\
\text { of earnings, and the sum of } \\
\text { equity physical capital } \\
\text { which is shown in balance } \\
\text { of payment as well as short- } \\
\text { term and long-term capital } \\
\text { stock. }\end{array}$ & WDI \\
\hline GDP Deflator & GDP-D & Annual \% & $\begin{array}{l}\text { Inflation as calculated } \\
\text { through the yearly growth } \\
\text { rate of the GDP contained } \\
\text { deflator explains the speed } \\
\text { of price change in the entire } \\
\text { economy. The GDP deflator } \\
\text { is the ratio of nominal GDP } \\
\text { to real GDP. }\end{array}$ & WDI \\
\hline Discount rate & DR & $\%$ & $\begin{array}{l}\text { DR refers to interest rate } \\
\text { accused the commercial } \\
\text { banks and other monetary } \\
\text { organizations for credit or } \\
\text { loans }\end{array}$ & IFS \\
\hline
\end{tabular}




\section{Model Specification}

All the above variables for the model are selected from the literature. The model pursues the neoclassical Solow growth framework. The model is used by Baghebo and Edoumiekumo (2012); Kalu and Mgbemena (2015a) and Haque (2013) in similar studies. The growth model framework takes the form of the Cobb-Douglas function as followed:

$$
Y=A f(K, L)
$$

$A=$ Technological shift

$Y=$ Output

$K=$ Physical capital

$L=$ Labor force

$f=$ Functional details of the possible total output

The production function revolves on the hypothetical statement that inputs (investment) return productivity (economic growth). Hence the practical demonstration of the association is:

$$
R G D P=f(D C P S, F D I, D R, G D P-D)
$$

The equation can be specified as

$$
\text { lRGDPt }=\beta o+\beta 1 \text { lDCPSt }+\beta 2 \text { FDIt }+\beta 3 \text { DRt }+\beta 4 \text { GDP_Dt }+\mu t
$$

Where $\beta \mathrm{o}=$ the constant expression is implicit in taking into account the growth of productivity and other left-out exogenous variables. $\beta 1, \beta 2, \beta 3, \beta 4=$ slop Coefficients, $t=$ time, $\mu=$ Stochastic term and $l n=$ natural log.

\section{Method of Data Analysis}

To estimate the equation, first, the stationarity of the series I chehcked by using Augmented Dickey-fuller (ADF) unit root test, because non-stationary variables provide a spurious regression. Unit root test is used to check whether the variables are in different order of integration to fit in ARDL method. The ARDL bound testing approach developed by Pesaran and Shin (1998) is used to observe the association between credit availability to private sector and economic growth. After running the regression, F-statistic are computed to check the long-run association of the variable. The hypotheses for co-integration relation are given below:

Null hypothesis:

Alternative hypothesis:

$$
H o=\beta o=\beta 1=\beta 2=\beta 3=\beta 4=0 \quad \text { (No co-integration) }
$$

$$
H 1=\beta o \neq \beta 1 \neq \beta 2 \neq \beta 3 \neq \beta 4 \neq 0 \quad \text { (Cointegration exists) }
$$

If the value of F-statistic is more than the upper bound I (1) of critical value then we say that co-integration exists and long-run association is present.

\section{Empirical Results \\ Unit Root Test}

Initially, we ensure the Stationarity of data to avoid spurious regression. This experiment checks the Stationarity of data. For this reason, we will employ an augmented dickey-fuller test-Table 2 presents the result of ADF at level and first difference. According to the results, LRGDP and LDCPS are in order of integration I(1), whereas DR and GDP-D are in order of integration $\mathrm{I}(0)$. 
INTERNATIONAL JOURNAL OF ACADEMIC RESEARCH IN BUSINESS AND SOCIAL SCIENCES

Vol. 11, No. 4, 2021, E-ISSN: 2222-6990 @ 2021 HRMARS

Table 2: Augmented Dicky-Fuller Test

\begin{tabular}{|c|c|c|c|c|c|}
\hline \multirow[t]{2}{*}{ Variables } & \multicolumn{2}{|c|}{ t-statistics } & \multicolumn{2}{|c|}{ ADF test $P$-values } & \multirow{2}{*}{$\begin{array}{l}\text { Order of } \\
\text { integration }\end{array}$} \\
\hline & Level & $1^{\text {st }}$ Difference & Level & $1^{\text {st }}$ Difference & \\
\hline LRGDP & $\begin{array}{l}- \\
2.65911 \\
4\end{array}$ & -3.869289 & 0.2585 & $0.0054 * * * *$ & $\mathrm{I}(1)$ \\
\hline LDCPS & $\begin{array}{l}- \\
2.18756 \\
6\end{array}$ & -4.707736 & 0.4818 & $0.0000 * * * *$ & $\mathrm{I}(1)$ \\
\hline FDI & $\begin{array}{l}- \\
2.79307 \\
5\end{array}$ & - & $\begin{array}{l}0.0693 \\
* *\end{array}$ & - & $\mathrm{I}(0)$ \\
\hline DR & $\begin{array}{l}- \\
3.75132 \\
6\end{array}$ & - & $\begin{array}{l}0.0075 \\
* * * *\end{array}$ & - & $\mathrm{I}(0)$ \\
\hline GDP-D & $\begin{array}{l}- \\
5.06968 \\
7\end{array}$ & - & $\begin{array}{l}0.0002 \\
* * * *\end{array}$ & - & $\mathrm{I}(0)$ \\
\hline
\end{tabular}

$* *$ Significant at $10 \%, * * *$ Significant at $5 \%, * * * *$ Significant at $1 \%$ level

The findings indicate that LRGDP is integrated of order I(1) with drift, and DPI is integrated of I(1) without drift and trend. FDI, DR, GDP-D are order of integration I(0) with drift.

The primary assumption for using ARDL model is that variables are stationary at level I(0) and $1^{\text {st }}$ difference i.e., mixed order of integration. So, in this case we will use ARDL model because results show mixed order of integration.

\section{Lag Length Selection}

Figure 1 shows that the most favorable lag selection for all dependent and independent variables is AIC(-6.51) of the first model out of the top 20 models, which is the lowest and then selected for estimation. There are four lags that are selected for the dependent variable (LRGDP), no lag is selected for LDCPS, four lags are selected for GDP-D and FDI, and three lags are chosen for DR. 


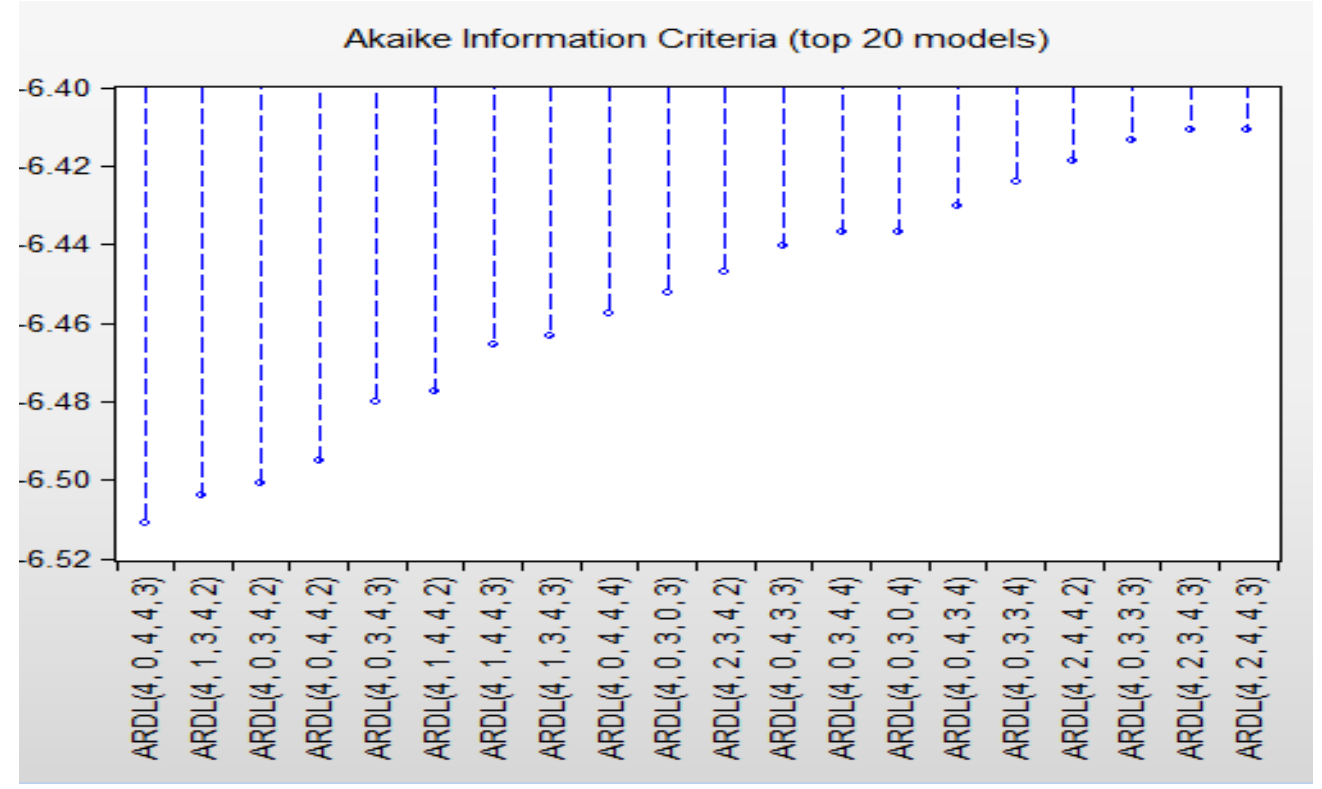

Figure 1: Akaike Information Criteria

\section{Cointegration Results}

Table 3 explains the results of bound test To identify the long-run relationship between variables. If the calculated F-stats are more than the upper bound, we can say that Cointegration exists. So, we can subject the equation to further analysis.

Table 3: Bound Test Results

\begin{tabular}{lccc}
\hline Calculated value of $\mathbf{f}-$ & Level of Significance & \multicolumn{2}{c}{ Critical Values of f-statistics } \\
\cline { 3 - 4 } Statistics & & $\mathbf{I ( 0 )}$ & $\mathbf{I ( 1 )}$ \\
\hline 5.43 & $1 \%$ & 3.74 & 5.06 \\
& $2.5 \%$ & 3.25 & 4.49 \\
& $5 \%$ & 2.86 & 4.01 \\
& $10 \%$ & 2.45 & 3.52 \\
\hline
\end{tabular}

\section{Interpretation}

Ho: No Cointegration

H1: There is Co-integration

The calculated F-statistics is 5.43 , which is more than the upper critical bound at $1 \%$ significance level. Lower bound I (0) is 3.74, and upper bound I(1) is 5.06 at $1 \%$ significant level. Therefore, we fail to accept the null hypothesis (Ho). So, there is a long-run association among LRGDP, LDCPS, DR, FDI and GDP-D over the period 1980-2017 in Pakistan.

\section{Long-run Coefficients}

Because all the observed variables are cointegrated, and the long-run coefficients of the ARDL model exist, Table 4 presents the results on the basis of selection of log length using the Akaike Information Criterion (AIC). 
Table 4: Long-run coefficients*

\begin{tabular}{lllll}
\hline Variable & Coefficient & Std. Error & t-statistics & P-value \\
\hline LDCPS & -0.721512 & 0.089838 & -8.031228 & 0.0000 \\
GDP-D & -0.053544 & 0.017410 & -3.075560 & 0.0082 \\
DR & -0.037760 & 0.021498 & -1.756489 & 0.1008 \\
FDI & 0.318066 & 0.039448 & 8.062833 & 0.0000 \\
C & 14.031260 & 0.663311 & 21.153371 & 0.0000 \\
\hline
\end{tabular}

* Dependent Variable is LRGDP

\section{Interpretation}

Table 4 indicates that there is a negative and significant relatioship between LDCPS and LRGDP at $1 \%$ level of significance; it employs that for $1 \%$ increase in LDCPS, there will be a decrease of $0.72 \%$ in LRGDP on average, keeping the effect of other variales constant in the long run. It also shows a negative and significant association between GDP-D and LRGDP that, for $1 \%$ increase in inflation there will be $0.05 \%$ decrease in LRGDP on average, keeping the effect of other variables constant. DR shows the negative and marginally significant relationship with LRGDP, and the last one is foreign direct investment (FDI), which shows a positive and highly significant relationship with LRGDP, it employs that for $1 \%$ increases in FDI there is $0.31 \%$ increase in LRGDP on average, if the effect of other variables is kep constant. The findings of the current analysis are the same as those of Fadhil and Almsafir (2015); Tahir et al. (2015), and Mohamed and Sidiropoulos (2008); they also show a negative but significant association among RGDP and domestic credit to the private sector.

\section{Short-run Coefficients}

The short run coefficients are given in Table 5.

Table 5: Short-run coefficients

\begin{tabular}{lllll}
\hline Variable & Coefficient & Std. Error & t-statistics & p-value \\
\hline D(LRGDP(-1)) & -0.580483 & 0.163113 & -3.558771 & 0.0031 \\
D(LRGDP(-2)) & -0.449072 & 0.186090 & -2.413194 & 0.0301 \\
D(LRGDP(-3)) & -0.509933 & 0.177188 & -2.877922 & 0.0122 \\
D(LDCPS) & -0.084076 & 0.038283 & -2.196151 & 0.0454 \\
D(GDP_D) & -0.000919 & 0.000610 & -1.507822 & 0.1538 \\
D(GDP_D(-1)) & 0.003076 & 0.000515 & 5.974777 & 0.0000 \\
D(GDP_D(-2)) & 0.001025 & 0.000579 & 1.770164 & 0.0985 \\
D(GDP_D(-3)) & -0.000542 & 0.000472 & -1.148675 & 0.2699 \\
D(DR) & -0.001304 & 0.001587 & -0.821636 & 0.4251 \\
D(DR(-1)) & 0.001893 & 0.002163 & 0.875139 & 0.3963 \\
D(DR(-2)) & 0.001710 & 0.001638 & 1.043643 & 0.3143 \\
D(FDI) & 0.026024 & 0.008389 & 3.102261 & 0.0078 \\
D(FDI(-1)) & 0.012114 & 0.008049 & 1.505071 & 0.1545 \\
D(FDI(-2)) & -0.004454 & 0.007228 & -0.616234 & 0.5476 \\
D(FDI(-3)) & -0.007805 & 0.005606 & -1.392284 & 0.1856 \\
\hline CointEq(-1) & $-\mathbf{0 . 1 1 6 5 2 7}$ & $\mathbf{0 . 0 5 4 7 4 3}$ & $\mathbf{- 2 . 1 2 8 6 3 8}$ & $\mathbf{0 . 0 5 1 5}$ \\
\hline $\mathbf{R}^{\mathbf{2}}$ & $\mathbf{0 . 9 3 9 0 9 1}$ & Adjusted $\mathbf{R}^{\mathbf{2}}$ & $\mathbf{0 . 8 5 6 4 2 9}$ \\
\hline F-stat & $\mathbf{1 1 . 3 6 0 6 4}$ & Durbin-Watson stat $\mathbf{2 . 1 7 2 7 2 7}$ & \\
\hline
\end{tabular}

* Dependent variable is $\Delta$ LRGDP 


\section{Interpretation}

The coefficient of Error correction term (-0.116527) is significant at $5 \%$ level with a negative sign that tells us the survival of long-run connection among the variables. Estimated coefficient cointEq(-1) indicates a 0.37 adjustment speed in the long run. It mean the system can achieve long-term stability at the velocity of $11 \%$. Table 5 shows the insignificant effect of DR and FDI on economic growth in the short run. Insignificant or small coefficients indicate the private investment is a long-term procedure. It means that if private investors invest in the current period, the results are shown in the next year or after a long time. In the shortrun, effect of credit to private sector is negative at a $5 \%$ significant level, consistent with longrun results. $R^{2}$ is 0.93 , which shows that the model is well-fitted.

\section{Conclusion}

The study examines the impact of private investment on economic growth in Pakistan from 1980-2017. It is found that a long-run relationship between the dependent and explanatory variables is present. This research identifies that the domestic credit to private sector and GDP deflator have a negative and significant effect on economic growth, and FDI has a positive and significant impact on Pakistan's economic growth. Another finding shows that discount rate has a negative or marginally significant effect on economic growth in Pakistan. It is concluded that domestic credit to the private sector is negatively related to economic growth, especially in the long run.

\section{Policy Implications}

Being a developing country, Pakistan depends on foreign assistance or foreign loans. Foreign loans impact negatively both in long and short run, yet they also discourage private investment in Pakistan. The main reason for negative private investment coefficient is that most people are uneducated or unaware of technological advancement in Pakistan. They are unable to handle the latest technologies and the capital is wasted or not fully utilized. In such circumstances, private investment is more risky and private investors cannot invest in these situations because private investors' main aim is to maximize profit.

Political instability is also a significant problem in Pakistan. We know that public investment is deposing private investment, so government structure is very important for private investment. If the government wishes to enhance private investment, it must focus on institutional quality, and better business environment. Better quality of institution increases private investment, and resultanly economic growth increases. If these problems are addressed propery, then the effect of private investment in the future may be optimistic.

The study recommends that Pakistan needs to work on the labor side of the economy; people are unfamiliar with the latest technology and the rate at which they become adapted is very low. This reduces the productivity in the country in the long-run, and also discourages the private investors. The negative effect of private investment is probably the lack of sound economic environment in the country. Besides human capital the political instability and natural disasters also put limit to the productive capacity of the country.

\section{Limitation of the Research}

- In this study, the sample size is 38 years (1980-2017), which is not adequate to represent the results, and there can be some structural breaks during this time span that may affect the results. 
- The study employs ARDL model, while it is quite possible that the use of other econometric models may produce different and accurate results.

- The use of proxy variables for some economic indicators may not yield the expected results.

- In this study, 4 independent variables are used to study the impact on economic growth. If more variables like exchange rate, population and foreign portfolio investment are added as explantoey variables, then it may allow us to give better prediction about the economy

\section{Authors Contribution}

All authors contributed equally in designing, data collection, assimilation, and writing of this manuscript, and the final version was read and approved by all authors.

\section{Conflict of Interest}

The authors declare no conflict of interest.

\section{Submission Declaration}

We hereby confirm that the manuscript has no actual or potential conflict of interest with any parties, including any financial, personal, or other relationships with other people or organizations within three years of beginning the submitted work that could inappropriately influence or be perceived to influence. We confirm that the paper has not been published previously, it is not under consideration for publication elsewhere, and the manuscript is not being simultaneously submitted elsewhere

\section{References}

Abdaljawwada, O. N. A., \& Sarmidi, T. (2018). Private Sector Investment and Economic Growth in Palestine (1990-2015). International Journal of Islamic and Civilizational Studies.

Ali, S., Hashmi, S. H., \& Hassan, A. (2013). Relationship between political instability and domestic private investment in Pakistan: A time series analysis. Pakistan Business Review, 15(1), 1-26.

Attefah, E. K., \& Enning, D. K. (2016). An OLS approach to modelling the determinants of private investment in Ghana. International Journal of Academic Research in Business \& Social Sciences, 6(4), 201-226.

Badawi, A. (2005). Private capital formation and macroeconomic policies in Sudan: application of a simple cointegrated vector autoregressive model.[ Retrieved from]. Paper presented at the Economic Research Forum.

Baghebo, M., \& Edoumiekumo, S. (2012). Domestic private capital accumulation and economic development in Nigeria (1970-2010). International Journal of Academic Research in Business \& Social Sciences, 2(5).

Bivens, J. (2012). Public investment: The next 'new thing'for powering economic growth. Economic Policy Institute, Briefing Paper, 338.

Djankov, S., Ganser, T., McLiesh, C., Ramalho, R., \& Shleifer, A. (2010). The effect of corporate taxes on investment and entrepreneurship. American Economic Journal: Macroeconomics, 2(3), 31-64.

Ekpo, U. N. (2016). Determinants of private investment in Nigeria: An empirical exploration. Journal of Economics \& Sustainable Development, 7(11), 80-92. 
Fadhil, M. A., \& Almsafir, M. K. (2015). The role of FDI inflows in economic growth in Malaysia (Time Series: 1975-2010). Procedia Economics \& Finance, 23, 1558-1566.

Fournier, J.-M. (2016). The positive effect of public investment on potential growth. OECD Library.

Haque, S. T. (2013). Effect of public and private investment on economic growth in Bangladesh: an econometric analysis. Research Study Series No FDRSO5/, Finance Division, Ministry of Finance.

Hundie, S. K. (2014). Savings, investment and economic growth in Ethiopia: Evidence from ARDL approach to co-integration and TYDL Granger-causality tests. Journal of Economics \& international finance, 6(10), 232-248.

Kalu, C., \& Mgbemena, O. (2015a). Banking Sector Reforms in Nigeria's Fourth Republic: A Review of Evidence'. Journal of Economics \& Sustainable Development, 6(6), 37-44.

Kalu, C., \& mgbemena, O. (2015b). Domestic private investment and economic growth in Nigeria: Issues and further consideration. International Journal of Academic Research in Business \& Social Sciences, 5(2), 302.

Kartikasari, D. (2017). The Effect of Export, Import and Investment to Economic Growth of Riau Island Indonesia. International Journal of Economics \& Financial Issues, 7(4), 663667.

Khan, S., \& Khan, M. A. (2007). What determines private investment? The case of Pakistan. Retrieved from https://ideas.repec.org/p/eab/financ/22202.html

Kirya, I. K., \& Yudiaatmaja, F. (2015). PENGARUH INVESTASI, TENAGA KERJA, DAN EKSPOR TERHADAP PERTUMBUHAN EKONOMI DI KABUPATEN BULELENG PERIODE 2008-2012. Jurnal Manajemen Indonesia, 3(1).

Mohamed, S. E., \& Sidiropoulos, M. (2008). Finance-growth nexus in Sudan: empirical assessment based on an application of the autoregressive distributed lag (ARDL) model. Üçüncü Uluslararası Öğrenci Konferansı "Social Sosyal Bilimlerde Ampirik Modelleme". Izmir Ekonomi Üniversitesi Yayınları, İzmir, Türkiye, 47-66.

Mohan, R. (2008). Growth record of the Indian economy, 1950-2008: A story of sustained savings and investment. Economic Political Weekly, 61-71.

Mohsen, A. S. (2015). Effects of exports and imports on the economic growth of Syria. EuroAsian Journal of Economics \& Finance, 3(4), 253-261.

Murty, K., \& Soumya, A. (2007). Effects of public investment on growth and poverty. Economics \& Political Weekly, 47-59.

Nwakoby, C., \& Bernard, A. U. (2016). Effect of private sector investment on economic growth in Nigeria. NG-Journal of Social Development, 417(3947), 1-18.

Osman, E. G. A. (2014). The impact of private sector credit on Saudi Arabia Economic Growth (GDP): An Econometrics model using (ARDL) Approach to Cointegration. Am Int J Soc Sci, 3(6), 109-117.

Popescu, G. H. (2014). FDI and economic growth in Central and Eastern Europe. Sustainability, 6(11), 8149-8163.

Samargandi, N., Fidrmuc, J., \& Ghosh, S. (2014). Financial development and economic growth in an oil-rich economy: The case of Saudi Arabia. Economic modelling, 43, 267-278.

Sari, M., Syechalad, M. N., \& Majid, S. A. (2016). Pengaruh investasi, tenaga kerja dan pengeluaran pemerintah terhadap pertumbuhan ekonomi di Indonesia. Jurnal Ekonomi Dan Kebijakan Publik Indonesia, 3(2), 109-115. 
Tahir, S. H., Shehzadi, I., Ali, I., \& Ullah, M. R. (2015). Impact of bank lending on economics growth in Pakistan: an empirical study of lending to private sector. American Journal of Industrial \& Business Management, 5(08), 565.

Tuan, C., Ng, L. F., \& Zhao, B. (2009). China's post-economic reform growth: The role of FDI and productivity progress. Journal of Asian Economics, 20(3), 280-293.

UN. (2019). The role of public investment in social and economic development. Retrieved from Geneva: https://unctad.org/system/files/official-document/webdiae20091_en.pdf 